\title{
Willing but Unable? Teachers' Sense-making of Curriculum-reform Policy in the Early Implementation Stage
}

\author{
Godsend T. Chimbi ${ }^{1}$, Loyiso C. Jita ${ }^{2}$
}

\footnotetext{
1 University of the Free State, Faculty of Education, P.O. Box 339, ZA-9300, Bloemfontein, Republic of South Africa, gchimbi1967@gmail.com

2 University of the Free State, Faculty of Education, P.O. Box 339, ZA-9300, Bloemfontein Republic of South Africa, JitaLC@ufs.ac.za
}

Abstract. This paper explores how history teachers in Zimbabwe interpret the new curriculum policy and how their understanding influenced the implementation of the new reforms. Using a qualitative multiple-case study of history teachers data were collected through document analysis, in-depth interviews and extensive non-participatory lesson observations. Results seem to challenge the traditional view that teachers are naturally resistant to change and are saboteurs who tend to undermine reform proposals. Instead teachers need to be empowered on how to implement the envisaged changes.

Keywords: Curriculum reform, policy, sense-making, reform implementation, history curriculum, history teacher.

\section{Introduction}

Implementation research, over the decades, has shown that curriculum reform is a complex and controversial process littered with anxiety, confusion, frustration and unfinished business (Cohen, 1990; Cuban, 1993; Fullan, 2000a; Spillane, Reiser and Reimer, 2002; Sahlberg, 2006; Zindi, 2018). Rarely are policies implemented as written or as intended by their initiators (Ganon-Shilonand Schechter, 2017); however, this has not deterred policymakers from rolling out new reform projects in an attempt to correct 
the shortcomings of previous reform initiatives. Traditionally, schools are seen as conservative institutions which are difficult to change (Fullanand Miles, 1992; McLaughlin and Mitra, 2001; Adams and Jean-Marie, 2011) and teachers as naturally resistant to reform because to change or to try something new often means to risk failure (Prendergast and Treacy, 2017). As a result, failure to implement reform at school and classroom levels has often been explained in terms of teachers' perceived dislike of curriculum change, school conservatism and/or resource shortages.

Although teachers are the final arbiters of reform implementation at the classroom level, what goes on in the teachers' minds upon receipt of reform signals from the policymakers and curriculum regulatory authorities has often been overlooked. Prendergast and Treacy $(2017,4)$ observe that very often, there is the simplistic assumption that 'teachers will, machine like, alter their behaviour because they are simply told what is good for them and for their students.' Very little research has been done in developing countries generally, and in Zimbabwe specifically, to examine how teachers make sense of reform policies before they decide on whether to implement or ignore them. Informed by the cognitive sense-making theory (Spillane, Reiserand Reimer, 2002; Coburn, 2006; Ganon-Shilonand Schechter, 2017), this paper challenges the view that teachers by nature tend to be resistant to change and/or are saboteurs who undermine reform proposals if the anticipated changes do not promote their interests. The paper thus focuses on history teachers' sense-making of reform policy and its subsequent implementation in the classroom. It explores the research question: How do history teachers make sense of the curriculum-reform policies that guide teaching practice in Zimbabwean secondary schools?

\section{The aim and The purpose of the article}

The aim of this article is to explore how history teachers make sense of the new curriculum-reform policy and how their understanding of the policy influences their selection of teaching methods in Zimbabwean secondary schools. The purpose of the paper is to contribute knowledge, to an often neglected subject, on the cognitive processing of newpolicy documents and/or guidelinesby teachers.

\section{The Reform Dilemma}

Zimbabwe recently introduced a new history curriculum called History Syllabus 4044 as part of the comprehensive New Curriculum Framework for Primary and Secondary Education 2015-2022 (MOPSE 2015). This is the third history curriculum reform initiative in Zimbabwe since independence in 1980. Pioneering reform policy brought in History 
Syllabus 2166 in 1990, which prescribed that: 'The involvement of the learner should be regarded as central in approaches to learning' (Ministry of Education and Culture, $1990,5)$. This was soon followed by the second wave of reform, in 2002, which ushered in History Syllabus 2167. Syllabus 2167 prescribed that:'teaching for this syllabus should involve problem-posing, problem-solving, role play, structured written exercises, and discussion' (ZIMSEC, 2002, 4).

In spite of the reforms, local research on history teachers' instructional practices shows that rote pedagogy and the uncritical reading of text continue to dominate history instruction (Chitate, 2005; Barnes, 2007; Moyo and Modiba, 2013; Mapetere, 2013; Moyo, 2014). The new History Syllabus 4044, like the others before it, demands that teachers use 'learner-centered and multi-sensory approaches' (CDTS, 2015, 2). But Syllabus 4044 differs from Syllabus 2167 (which it is replacing) in that it adds new learner - centred approaches like educational tours, research, debate, projects, folklore and computer based instruction in history teaching. The syllabus document states that: 'the teaching of History will be accomplished through the use of the following learner-centred and multisensory approaches: games and quizzes, simulation, video and film shows, educational tours, case study, projects, folklore and e-learning' (CDTS, 2015, 2). The initiation of this third-generation curriculum-reform initiative somewhat implies the failure of earlier reforms to change the way history teachers teach. Evidently, history teachers in Zimbabwe continue to face challenges in the implementation of learner-centred teaching methods as prescribed by the reforms, and thus, the policymakers are caught up in an endless dilemma of 'reforming again and again' (Cuban, 1990, 3). This paper, therefore, seeks to explore how history teachers make sense of the New Curriculum Framework 2015-2022 and how their sense-making shapes the early implementation of the new reforms in Zimbabwean secondary schools.

\section{Curriculum Policy and Practice}

There appears to be a wide gap between what curriculum-reform policy espouses and what teachers actually doin schools across the world. Prendergast and Treacy $(2017,1)$ make the general observation that 'in most schools [in the developed world] there is the common mismatch between the intended curriculum prescribed by policy-makers and the implemented curriculum that is actually carried out by teachers in their classrooms.' Similarly, Jansen $(2002,200)$ acknowledges the 'policy-practice gap' in post-apartheid education in South Africa, which is reflected in 'the preoccupation of the state with settling policy struggles in the political domain rather than in the realm of practice.' Throughout the world, there is a view that policy reforms are often initiated by governments for political expediency rather than any real commitment to filter the changes into schools and classrooms. 
Cohen and Ball (2006) observe the incompatibility between policy and practice during reform implementation. They see a 'dilemma' and observe that 'policy and practice are often portrayed as being in conflict or opposition, as policy makers attempt to secure compliance from implementers who respond by attending to their situations, or evade, or attempt to buffer themselves from policy' (Cohen and Ball, 2006, 518). Thus, the teachers who are the targets of change are also expected to be the agents of reform. However, instead of promoting reform (as expected by policy), the view is that teachers, at times, act as barriers to curriculum change. The puzzle becomes more complex when one considers that teachers are often considered to be part of the causes of policy reform, in part because of their poor classroom practices that necessitate policy changes. And yet, they are also part of the solution to the reform-implementation dilemma due to the fact that they are the final arbiters of reform policy at school and classroom levels.

The conventional view, especially in centralised systems, has been that policy acts as a guide to practice and teachers are expected to implement the reforms they receive from a central authority in a top-down, linear sequence. However, McLaughlin and Mitra (2001) established, as Cohen (1990) had done previously, that, up to the time of their study, policy had only affected practice weakly and inconsistently, if at all. This is the reason why Cohen and Ball $(2006,519)$ say that, 'some analysts view reform policy as an imposition on those who do the real work [the teachers].' Partly because reform is imposed on them, teachers have not changed their classroom practices much in response to reform policy signals.

The traditional approach to the implementation dilemma has been to see teachers as naturally resistant to change and to place the blame for a failure to implement reform policy squarely on the teachers' shoulders (Dube and Jita, 2018). The policy-practice gap has also been explained in terms of inadequate teacher preparation, inequitable resource allocation, resource shortages and resistance by parents. Tabulawa (2009) scorns the traditional assumption that allocating more money to reform implementation programmes would bridge the gap between reform-policy expectations and teachers' classroom practices. However, research in schools reveals that there is a weak and inconsistent relationship between resource provision and reform implementation, making researchers conclude that resource availability does not guarantee reform implementation by teachers (McLaughlin and Mitra, 2001; Sahlberg, 2006). Resources to support reform policy can be made available, but teachers may not utilise them to change their practices. This makes the relationship between policy and practice quite complex and non-linear, and therefore worth exploring in greater depth.

Reese $(2013,322)$ argues that, due to a multiplicity of inter-woven factors, 'progressive ideas are easier to proclaim than act upon.' This is mainly because passing reform policy legislation is much easier than reforming teachers' classroom practices. In some instances, teachers fail to implement reforms as expected because policymakers ignore the teachers' concerns to be empowered with knowledge and skills through continuous 
professional development so that they can understand the envisaged curriculum reforms (Gudyanga and Jita, 2018). In addition, at times, teachers find reformpolicy documents to be ambiguous and difficult to understand, making them ignore the changes and continue with the practices they are used to. Almost three decades ago, Cohen and Ball (1990, 238) made the point that it is difficult for teachers to 'teach mathematics that they never learned, in ways that they never experienced.' Teachers cannot teach what they do not know. They must learn new ideas and acquire new skills before they can implement a new curriculum. Failure by policymakers to adequately prepare teachers for the anticipated changes appears to be one major reason why teachers are perceived as resistant to reformpolicy implementation. When teachers are inadequately prepared to implement reforms, they are likely to continue teaching the traditional way - through rote pedagogy characterised by chalk and talk.

\section{Theoretical Framework}

The paper uses cognitive sense-making as the lens for exploring history teachers' interpretation and understanding of the 2017 curriculum reforms and how their understanding of policy shapes (or fails to shape) their classroom practices. Sense-making is used in this article to mean the way in which individuals gather, organise and reorganise information to build a plausible understanding of an aspect that is puzzling or troubling (Wheat, Attfield and Fields, 2016). Garfinkel coined the term 'sense-making' in 1967 in his ethnographic study on how film actors interact, interpret and construct reality in their daily experiences (Maitlis and Christianson, 2014, 60). Sense-making was also popularised by Weick (1995) when he looked at how changes in organisations make implementers react cognitively as they seek to construct meaning of how reforms are likely to affect their workloads, working style and self-image. Other scholars who have used sense-making as a theoretical framework for their studies include Fullan and Pomfret (1977), McLaughlin (1987), Cohen (1990), Spillane, Reiser and Reimer (2002), Coburn (2006), Maitlis and Christianson (2014), Wheat, Attfield and Fields (2016) and Ganon-Shilon and Schechter (2017).

The sense-making theory works for this article because it rejects the portrayal of teachers as 'resisters and saboteurs working to circumvent policy proposals that do not advance their selfinterest' (Spillane, Reiser and Reimer, 2002, 391). The theory sees teachers as active implementing agents who first process reformpolicy signals in their minds, construct the meaning of the reforms and then decide to implement, or ignore, the changes - depending on their understanding of reform policy - more than merely responding to the availability of instructional resources and external funding. When informed by the sense-making theory, curriculum implementation becomes an exercise in partnership (or a battlefield) between policymakers (who set out reform policy) and 
the teachers (who try to interpret, understand and implement a policy that may have been crafted in their absence).

\section{Methodology}

This paper forms part of a larger qualitative, multiple-case study of history teachers purposively sampled from four secondary schools in one urban school district in Zimbabwe. Purposive sampling techniques were used to select the four schools and the four history teachers that participated in this study. The four schools were carefully selected from 13 targeted secondary schools in the residential town because they were considered to have the best teaching-learning resources. The teachers selected were studied in their natural settings - the school and the classroom - because 'qualitative researchers observe people in their natural setting so that they can learn from them about what they are thinking, and more importantly, why they think and act the way they do' (Minichiello and Kottler, 2010, 12). This multiple-case study focuses on participants as separate individuals, rather than on groups (Creswell, 2013), and is appropriate in exploring each participant's individual sense-making of reform policy in the first year of implementing the reform initiative.

The four history teachers (one per school) purposively sampled for the present study pioneered the teaching of the new history curriculum (Syllabus, 4044) to Form 3 students (15-16 year olds) in 2017. A degree in history and a diplomain history pedagogy were also part of the sampling criteria. These qualifications empower teachers with the requisite knowledge of the different methods that can be used to teach history and the skills to interpret and make sense of fairly complex curriculumreform policies. In addition, each participanthad more than five years' teaching experience in the history classroom. Patton $(2002,230)$ observes that the logic and strength of purposive sampling is to select 'information rich cases' that can be studied over prolonged periods.

The researchers' roles in this multiple-case study were multi-faceted. Firstly, we analysed the reformpolicy documents that guide the history teachers in implementing the new history curriculum, specifically the curriculum frameworks, syllabuses, and circulars. Secondly, three indepth interviews (approximately an hour long each) were held with each participant, one each at the beginning, the middle and the end of an eightweek fieldwork period. Data from the interviews were tape-recorded and transcribed into written text. The transcripts were then coded and analysed through interpretation, triangulation, intra-case and cross-case analysis. This enabled us to search for patterns and uniqueness in the participants' sense-making of reform policy. Lastly, a total of 47 lesson observations were made over the eight-week period, with an average of close to 12 lesson observations per participant. A preformatted lesson-observation protocol was developed by the researchers to record the teaching methods the participants used, and 
then compare and contrast the lesson observations with the recommended pedagogical approaches in the policy documents.

Permission to carry out this study was granted by the relevant authorities at the University of the Free State and the Permanent Secretary for Primary and Secondary Education in Zimbabwe. The targeted participants were then informed of the purpose of the study and asked to volunteer themselves. After obtaining the participants' informed consent (through signing a written agreement) and ensuring their anonymity through the use of pseudonyms, one of the researchers (first author) spent eight weeks engaging with the participants at the research sites, moving between schools during this period. Data triangulation and member-checking were also used to ensure the trustworthiness and credibility of the data and findings emanating from this research.

\section{Findings of the Study}

Data gathered in this study sought to answer the main research question: How do history teachers make sense of the curriculum-reform policies that guide teaching practice in Zimbabwean secondary schools?

\section{Chaos and Confusion}

The results suggest that the four participants had different interpretations of the official reform policy documents, although there are some common threads that run through their sense-making of the policy guidelines. Angela saw the new curriculum as characterised by confusion and inconsistency. She complained that, 'the new curriculum means confusion because one day you are told this, the next day you are told the other thing. You do this and then you are told it's wrong.' She pointed out that policymakers were changing the goalposts because,'at one time they were talking of the new curriculum, but now they are saying it is an updated curriculum.' This created confusion in Angela's mind. Her frustrations with the sense-making of the new curriculum speaks to the observation by Chater and Loewenstein $(2016,141)$ that,' $[\mathrm{t}] \mathrm{he}$ feeling that there is sense to be made, but we are unable to make it, can be agonizing and this explains why we find stimuli aversive when they are surprisingly difficult to make sense of.' Teachers often get frustrated when they fail to make meaning of reform and this experience can also be painful.

Equally frustrating for Angela was the experience she had when she thought that she had made sense of policy intentions and was implementing the new curriculum, only to be told that it was not a new curriculum but an updated one. She had to recast her sense-making and try to create new meaning out of the reform policy signals. Angela also complained that: 'The new syllabus requires us to use the internet, interactive boards, white boards, projectors, but all these things are not there...' In the 13 lessons 
she was observed teaching;Angela did not make use of most of the teaching methods recommended in the new history curriculum citing the lack of resources. As a result, she relied a lot on teacher exposition, dictation and note giving making learners passive listeners in her lessons.

For Bessie, on the other hand, the new curriculum meant a refreshing new experience to history instruction. She welcomed the new curriculum as it allowed her the opportunity to use the new pedagogical, computer and research skills she acquired during her studies for the Bachelor of Education (B. Ed.) Degree in History: 'I did not have any problem with the new curriculum. I accepted it from the beginning. 'Thus, Bessie, unlike the other three participants in this study, had a favourable attitude towards the new curriculum since its inception in schools in January 2017. 'This was because of the B.Ed. Degree in History - some of the skills that I gained in the degree programme put me above some other teachers. The new methods in the new curriculum were familiar to me as I had covered them at university in the pedagogics course,' she explained in the pre-observation interview. Spillane $(1999,549)$ observes that the meaning of reform policy will differ from one teacher to another because,'policy signals do not present policy problems and policy solutions as givens: rather, the meaning or message of a policy signal is constructed by local enactors in the interaction of policy signals with their knowledge, experiences and situation.' Bessie, as with the other three participants in the study, interpreted reform policy according to the knowledge she possessed and the school context she operated in.

In the 10 lessons she was observed teaching; Bessie did not make use of most of the learner-centred methods prescribed in the new syllabus. The only prescribed methods she used were pair work, discovery learning (through text study) and class discussion. She did not make use of video and film shows, educational tours and e-learning. Asked why she explained that:

The video player we have in the staffroom for teachers is not working. So we cannot talk of video for pupils when the one for teachers is not even working... These trips have got some procedures, and the procedures are so tiresome and so engaging, in the end, you give up. Clearance from Ministry, consent from parents and you also need money from parents to finance the trip. And the money is simply not there".

David saw no difference between the new curriculum (History Syllabus, 4044) and the old curriculum (Syllabus, 2167) he had been teaching since 2002. To him, the changes brought by Syllabus 4044 were cosmetic rather than fundamental. 'It is the same John we are today calling Thomas because we don't have new topics,' he remarked. He added that: 'The topics we were studying in the previous syllabus [2167] are the same topics we are studying in the new syllabus [4044]. But in a nutshell, the new curriculum has two new aspects. It has this idea of coursework and projects which we call continuous assessment.' However, heelaborated that he did not clearly understand the intentions and purposes of the new curriculum policy, although he had already been implementing it. This is how he put it: 'This new curriculum thing is a new baby; we are not very 
clear right from the top to the bottom. We are still learning.' David did not see the lack of clarity about the new curriculum as a problem unique to him,but as a problem for everyone, from the policymakers at the top, down to the teachers in the classroom. In the nine lesson observations made in David's Form 3D he used some learner - centred methods recommended in the new history syllabus like; discovery learning (through text study), research, class presentations, discussion and debate. But he also relied a lot on teacher-centred methods like teacher exposition, note giving and dictation arguing that: 'The history teacher remains the master of the subject. Here and there the teacher must give students notes because it's not everything which is found in the school textbook.'

Emmy also narrated her ordeal with the new curriculum:

Form I, Form 3 and Form 5 are all involved in the new curriculum, and I am teaching all these classes. I don't even know where we are going and what is going to happen because we hear there are projects, but we haven't seen anything, even the specimen papers, question papers, we haven't seen them. So, we are actually teaching from the head. We don't know where we are going. Even with our questions, we are just setting our own questions. This is the major challenge.

Emmy'semarks reinforced Angela and David's observations that confusion and anxiety were some of the major challenges teachers faced in making sense of the 2017 curriculum reforms.But in the 15 lessons, Emmy was observed teaching in Form 3E, she used most of the methods recommended in Syllabus 4044 specifically: group work, group discussion, discovery, research, class presentations, debate, role play andprojects. Emmywas the only participant in this study who went on educational tours with her history students. She explained that: 'We visited the National Archives and the Heroes Acre here in Harare in July 2017... We have not done any excursions outside Harare in 2017 mainly because of financial constraints.'Emmy lived up to what she had always insisted on the interviews: 'in all my classes I have always used progressive methods. Even before the new curriculum, I had already moved from that teacher-dominated approach.'

\section{'Fast-tracking' the Reforms}

The other major finding in the present study is that all the participants, except for Bessie, felt that the reforms were hurriedly introduced, without adequate teacher preparation. Angela explained her bitterness:

It was too late when we were informed of the new curriculum, and the workshops held were just insufficient. In fact, we did not learn anything from the workshopmainly because all departments from different subjects were in the same room, whether history, economics, mathematics ... People training us were our fellow teachers, who were handpicked and trained for two days only. They were inadequately trained. They could not answer all of our questions... We haven't seen any specimen paper. 
Angela saw the lack of professional staff development as the major impediment to teachers' sensemaking of the new history curriculum. According to her, teachers lack knowledge on the interpretation and implementation of the new history curriculum because they were not adequately inducted into it, but were only learning about the new curriculum as they were implementing it.

David shared similar sentiments with Angela. He also complained that:

I don't think that teachers were adequately prepared. Before implementation of a new syllabus, teachers must have a number of workshops to interpret the new syllabus, to prepare the teaching aids... I think we should have had what I call a pilot project to test the feasibility of these changes, so that modifications can be made where there is a need.

Emmy also felt that,'This new curriculum has been a major challenge because, initially, we did not have much information on the changes. It was abrupt, it was not given time and we didn't have workshops to prepare us. I don't even know where we are going.' These snippets from the interviews seem to indicate that most teachers were not clear on what the new curriculum meant and what they were supposed to do to bring changes to their classroom practices, creating confusion and anxiety in their minds. However, Cohen $(1990,323)$ advises that, even if the best implementation plan is put in place, 'confusion, and some sort of mixed practice, seem inevitable' in the early implementation stages of a reform. Findings from the present study seem to concur with Cohen's (1990) observations because confusion, anxiety and frustration characterised Angela, David and Emmy's sense-making of the reform policy in the first year of implementing the new history curriculum.

Only Bessie claimed to have adequate knowledge of the new curriculum. This is how she put it:

When I came back[from university] beginning this year, 2017, I started to see the teaching of history with another eye, with another view. And I was so stimulated, so motivated by the new curriculum; because while at university, we were equipped with various approaches that are learner-centred, like the seminars, presentations and research. That helped me a lot. My B.Ed. training helped me accept the new curriculum.

It looks like Bessie's B.Ed. studies at university prepared her,unwittingly, for the implementation of the new history curriculum because the content taught in the degree programme seemed to match the demands of the new history curriculum. This made Bessie accept the new curriculum from its inception in January 2017.

\section{Willing but Unable? The Paradox of Reform Implementation}

The four participants appeared willing to implement the new history curriculum, although some felt that they were forced to accept the new curriculum and were not 
adequately prepared for the implementation process. Angela, whom we describe as 'the soul rebel' because of her unrelenting criticism against the introduction of the new curriculum and its implementation, explained why she was implementing the new curriculum:

I am not resisting. I am complying as a matter of policy, but deep down my heart I am not convinced. Yes, we are implementing because that is what we are instructed to do. That is what the employer wants us to do, but the truth - on the ground it's difficult to do so, and it's impossible. Why? Because the implementation is actually dictated upon teachers. It's forced upon teachers and the requirements are unrealistic. And the research tasks are a total failure. I think they are a total failure.

From these words, one can infer that Angela was only implementing the new history curriculum to avoid possible sanctions for non-compliance by her employer. Circular No. 2 of 2017 (from the Permanent Secretary of Primary and Secondary Education) instructed that,'Internal and external supervision shall be undertaken to ensure effective implementation of the New Curriculum' (MOPSE, 2017, 2). We asked Angela if her attitude towards the new curriculum had changed as time had passed. Her answer wasclear:'It has never become positive because the implementation is dictated upon teachers.' Angela's hard feelings against the new curriculumseem to concur with Zindi (2018, 25), who found that,'teachers generally harbour negative and unconstructive feelings about the new curriculum.' Though frustrated and angered by dictated reform policy, Angela still felt that, 'these reforms are necessary because, at times, we were teaching irrelevant history to our modern children. For example, the transition from the late Stone Age to the Iron Age - personally, I don't see its value to the modern child...' Angela was thus not totally against curriculum reform;she was critical of the present reform framework which, in her opinion, was imposed on the teachers by the policy reformers.

David, like Angela, felt that there is nothing wrong with curriculum reform because change is not only inevitable, but necessary. 'Usually, in history, we believe that teachers who do not change face extinction, like the dinosaurs. You cannot escape being progressive,' he said. It can be deduced that David was not totally against curriculum reform because he believed that reform cannot be avoided and that it is beneficial. David explained his willingness to reform but his inability to do so because of the way the new framework was being disseminated into schools:

But currently, they [policymakers] are not working with teachers. They are just using this 'elite-mass' model of implementation inwhich the teachers are the unquestioning masses and the policymakers are the decisionmaking elite. Nowadays, I am a proponent of the rational model of policy implementation whereby all stakeholders must be adequately consulted beforethe implementation of any change.

It was the non-consultation of teachers and rushed dissemination of the new curriculum into schools which initially made David dislike the reforms. David's attitude 
towards the new curriculum went through a period of metamorphosis - from rejection to gradual acceptance - during the first year of implementing the reforms.

Like David, Emmy did not like the new curriculum, at first. 'We received it with resistance,' she said, and went on to explain that,'We did not like the new curriculum because already we have our museums of knowledge. We have our past exam papers for our students, and now we have to start afresh. So, we did not like it. I personally did not like it.' It was only with the passing of time and interacting with teachers from other schools that Emmy saw some positive aspects in the new curriculum. She also realised that there was little choice except to accept the policy prescription. This is how she explained her change of attitude over time:

Initially, when it was introduced, we were negative about it, but with time we actually realised that the new curriculum is there to stay and so we have to adapt and comply. Getting information on what is happening from others also helped us to accept the new curriculum. Some resistance is caused by ignorance and lack of knowledge. We did not have enough seminars, enough workshops on the new curriculum; it was hurried, so that is why we were a bit reluctant to accept the new curriculum. But now we are in full swing and the new curriculum is not as bad as we initially thought.

With her change in attitude,Emmy soon realised that she was already using most of the learnercentred approaches recommended in the new history curriculum. She related: 'In my classes, I have always used progressive methods. Even before the new curriculum, I had already moved from the teacher-dominated approach.'She was asked why and explained:

The progressive methods are exciting; children participate and they understand better - they are motivated. Even the examination results actually show that when children do it, they will understand better and pass...I realized thatI have been using these learner-centred methods; they are not new. To me, the new methods are old. I have been using them before the new curriculum, so it's just a continuation.

It is interesting, if not ironic, that Emmy initially hated the new history curriculum without realising that she was already using teaching methods the new curriculum advocated for, mainly because she lacked knowledge and information on the new curriculum and her sense-making of the changes was incomplete.

We labelled Bessie 'the cool embracer' because she accepted the new curriculum from the beginning. She did, however, lament the lack of implementation mechanisms to translate reform policy into practice:

We are in a process of learning how to go about it. Some of us are still in a state of confusion and are asking,How do we do this? Teachers are partially equipped on the new curriculum because, like I said, some of us are struggling and they are finding it difficult to understand how the new procedure must be done. Many questions are 
being asked: How do you go about the new curriculum? When are we supposed to hand in these things [research tasks]? How are we going to assist the children? At times, there are more questions than answers.

Thus, despite her positive attitude towards the new history curriculum from its inception, Bessie was also anxious that the policymakers did not adequately prepare the teachers for the implementation process. She also had her own grey areas on the new curriculum and was 'still in a state of confusion,' although she had claimed earlier that her B.Ed. Degree had adequately prepared her for the new curriculum.

\section{Discussion}

\section{Too Much Haste Spilling the Yam}

Policymakers in both developed and developing countries tend to often rush curriculum-reform legislation and roll-out changes into schools without taking steps to prepare teachers with knowledge and skills on how to implement the changes at classroom level (Fullan, 2000b; Ganon-Shilonand Schechter, 2017). Lack of knowledge on the change process partly explains why Angela, David and Emmy disliked the new curriculum at its inception. Except for Angela, who continued to harbour illfeelings toward the new history curriculum, David and Emmy gradually came to like the new curriculum as they received more information on it. For Emmy, this change of attitude occurred when she realised that, 'the new curriculum is not as bad as we initially thought.'Desimone's $(2002,444)$ research in the USA reveals that the schools where reforms are less successful are those where teachers have difficulties making sense of reform policy. In the present study, Angela, David and Emmy talked of the confusion and chaos that characterised the implementation of the new history curriculum in their schools. Their confusion was mainly because they did not have enough information on the changes and the workshops held were inadequate to prepare them for reform implementation.

The problem of introducing curricular reforms without adequate teacher preparation is not new or unique to Zimbabwe. It appears to be a common problem in most developing countries, especially where reforms are initiated by central governments that are far removed from the realities in the schools. Phiri $(2015,1)$, for instance, strongly criticises the Zambian government for introducing the 2013 curriculum reforms without preparing the schools and the teachers for the changes:

The new education curriculum is actually a mess. Computer Studies is now a compulsory subject at junior secondary. This is despite the ministry knowing that the majority of its teachers are computer illiterates. Up to this day, the computerilliterate teachers haven't been given textbooks to share their ICT hallucinations with the children. 
Findings from the present study seem to lend some support to existing literature which indicates that teachers often lack knowledge of the reforms they are expected to implement, mainly because they are inadequately inducted and trained for the changes. More than two decades ago, Fullan and Miles $(1992,747)$ found that in the USA, '[s] chools, districts and states were under tremendous pressure to reform. Innovation and reform are big business, politically and economically. The temptation is to go along with the trend.' Cuban $(2003,5)$ sees reforms in American schools as 'essentially a series of political acts.' It seems that, throughout the world, curriculum reform is often initiated more out of political expediency than a genuine commitment to change the education system. Jansen $(2002,199)$ uses the lens of 'political symbolism' to explain why reforms in developing countries in general, and post-apartheid South Africa in particular, are 'replete with narratives of "failure" ...despite unprecedented investments in policymaking and policy production.' He explains that most reform initiatives fail to take root in the classroom simply because the policymakers (who initiate and announce the changes) never mean to have them implemented in the first place. Nevertheless, even when policymakers have the will to implement change, the teacher is the final arbiter in reform implementation.

\section{Sense-making and Teachers' Concerns}

Gudyanga and Jita (2018) in their study used the Concerns Based Adoption Model (CBAM) to explore the seven Stages of Concern (SoC) teachers typically go through when they are faced with a new curriculum innovation. The first stage is the unconcerned stage. At this stage, the teacher totally ignores the reform or has a very low priority for it. All four participants in the present study appeared to have passed this stage as they were all concentrating on implementing the reforms, although Angela was implementing the reforms more as a matter of policy than out of a free will.

Angela appeared to be operating at the second and third stages of the SoC model: the informational and personal stages, respectively (Gudyanga and Jita 2018, 409). At the informational stage, the teacher searches for new knowledge on the reform. Angela appeared to be partly at this second stage because she lamented that,'We are implementing in confusion. We do corrections every day. We do research every day and go to the students again to correct the errors.' She also seemed to be operating at the personal level of concern (the third level), which is characterised by confusion, uncertainty and the teacher's feelings of inadequacy to meet the demands of the new curriculum. Angela complained that, 'the new curriculum means confusion because one day you are told this, the next day you are told the other thing. You do this and then you are told it's wrong.' Confusion and anxiety characterised Angela's sense-making of reform policy in the early implementation stage.

Bessie, however, seemed to be operating at the fourth level of the SoC model - the management stage. She explained that: 'We are in a process of learning how to go about 
it. Some of us are still in a state of confusion and are asking, How do we do this?' Bessie was concerned with organising, managing and ensuring implementation efficiency of the reform she had already accepted, although there was some confusion on the implementation modalities.

David appeared to be operating at the collaboration stage (level 6), which focuses on 'coordinating and cooperating with others regarding using the innovation' (George, Hall and Stiegelbauer, 2013, 8). David complained that:'But currently they [policymakers] are not working with teachers. They are just using this 'elite-mass' model of implementation in which the teachers are the unquestioning masses and the policymakers are the decision-making elite.'David was advocating for collaboration between policymakers and the teachers to ensure the successful implementation of the history curriculum reform.

The last stage in the CBAM is the 'refocusing stage', which emphasises 'exploring ways to reap more universal benefits from the innovation' (George, Hall and Stiegelbauer, 2013, 8). Emmy appeared to be operating at this stage as she was ahead of reform policy and was using the new curriculum to refine her already progressive practices. She maintained that: 'In my classes, I have always used progressive methods. Even before the new curriculum, I had already moved from the teacher-dominated approach.'In their study on the implementation of Environmental Education (EE) in South Africa, Jita and Mokhele (2013, S129) found that Mrs Mafolofolo'had started including EE in her teaching of Natural Sciences even before the changes to include it in the curriculum were drafted.' This was because she wanted students to 'see, touch and feel real life specimen.' There are close similarities between Mafolofolo and Emmy's pro-active classroom practices as both teachers seemed to be working ahead of the policies that are supposed to guide them. Such pro-active and reform-oriented teachers appear to be a rare species as they have the intrinsic drive to involve students in a variety of learning activities.

\section{Conclusion}

The way in which the four participants received and made sense of the new curriculum in Zimbabwe seem to challenge the commonly held views that teachers are naturally resistant to change and are not willing to learn new ideas and skills (Fullanand Miles, 1992; McLaughlin and Mitra, 2001; Adams and Jean-Marie, 2011; Prendergast and Treacy, 2017). The main argument presented in this paper is that it is an overstatement to assume that teachers by nature dislike change and are not willing to acquire new knowledge and skills. It would appear like all four participants in the present study were eager to obtain new information on the new curriculum and to implement it, although one of them was only doing it as a matter of routine and not out ofa free will. The threat of supervision to enforce implementation of the new curriculum compelled Angela to comply with the policy, although in her mind she was not convinced of the need to change her classroom practice. 
Lack of knowledge on the change process made the participants appear resistant to change at the initiation stage, when, in fact, they merely lacked information on the reforms. Giving new syllabuses to teachers does not necessarily make them change their classroom practice. The policy implications of these findings are that teachers need to be empowered with knowledge on reform policy and be (re)skilled to implement change. It is perhaps critical to engage teachers in extensive training programmes (not onceoff workshops) on the meaning, necessity and mechanisms of implementing reform before rolling out changes into schools. Teachers may need to form curriculum-reform committees to engage in and familiarise themselves with the reform-policy discourse at school, cluster, district and national levels. Furthermore, it may be useful if subject representatives stand up for teachers' interests at the different levels of the policymaking processes and hierarchies.

\section{References}

Adams, C. M., and Jean-Marie, G. (2011). A Diffusion Approach to Study Leadership Reform. Journal of Educational Administration, 49(4), 354-377.

Barnes, T. (2007). 'History has to Play its Role': Constructions of Race and Reconciliation in Secondary School Historiography in Zimbabwe, 1980-2002. Journal of Southern African Studies, 33(3), 633-651.

CDTS (Curriculum Development and Technical Services). (2015). History Syllabus 4044 Forms 1-4. Harare: CDTS.

Chater, N., and Loewenstein, G. (2016). The Under-appreciated Drive for Sense-making. Journal of Economic Behaviour and Organisation 126, 137-154.

Chitate, H. (2005). Post-independent Zimbabwe’s New ‘O’ Level History Syllabus 2166: A Crisis of Expectations. Zimbabwe Journal of Educational Research, 17(3), 1-30.

Coburn, C. E. (2006). Framing the Problem of Reading Instruction: Using Frame Analysis to Uncover the Micro Processes of Policy Implementation. American Educational Research Journal, 43(3), 342-379.

Cohen, D. K. (1990). A Revolution in One Classroom: The Case of Mrs Oublier. Educational Evaluation and Policy Analysis, 12(3), 311-329.

Cohen, D. K., and Ball, D. L. (1990). Policy and Practice: An Overview. Educational Evaluation and Policy Analysis, 12(3), 233-239.

Cohen, D. K., and Ball, D. L. (2006). Educational Innovation and the Problem of Scale: A Paper Presented at a Meeting on 'Conceptualising Scale-Up'. The University of Chicago: Data Research and Development Centre.

Creswell, J. W. (2013). Research Design: Qualitative, Quantitative and Mixed Methods Approaches ( $4^{\text {th }}$ Ed.). London: Sage.

Cuban, L. (1990). Reforming Again, Again, and Again. Educational Researcher, 19(1), 3-13. 
Cuban, L. (1993). The Lure of Curricular Reform and its Pitiful History. Phi Delta Kappan, 175(2), 82-185.

Cuban, L. (2003). The Blackboard and the Bottom Line: Why Schools Can't be Businesses. Education: Magazine of the Harvard School of Education Fall Issue, 1-5.

Desimone, L. (2002). How can Comprehensive School Reform Models be Successfully Implemented? Review of Educational Research, 72(3), 433-479.

Dube, B., and Jita, T. (2018). Rethinking Healthy School Relations for Curriculum Change in Zimbabwe: A Relational Leadership Approach. Issues in Educational Research, 28(4), 901-917.

Fullan, M. (2000a). The Three Stories of Education Reform. Phi Delta Kappan International, 1-9. Fullan, M. (2000b). The Return of Large Scale Reform. Journal of Educational Change, 1, 1-23.

Fullan, M., and Pomfret, A. (1977). Research on Curriculum and Instruction Implementation. Review of Educational Research, 47(2), 335-397.

Fullan, M., and Miles, M. B. (1992). Getting Reform Right: What Works and What Doesn't. Phi Delta Kappan, 73(10), 745-752.

Ganon-Shilon, S., and Schechter, C. (2017). Making Sense While Steering Through the Fog: Principals' Metaphors Within a National Reform Implementation. Education Policy Analysis Archives, 25(105), 1-33. http:/ / dx.doi.org/10.14507 / epaa.25.2942.

George, A. A., Hall, G. E., and Stiegelbauer, S. M. (2013). Measuring Implementation in Schools: The Stages of Concern Questionnaire. Austin, Texas: SEDL. http://www.sedl.org/pubs/catalog/ items/cbam17.html.

Gudyanga, R., and Jita, L. C. (2018). Mapping Physical Sciences Teachers' Concerns Regarding the New Curriculum in South Africa. Issues in Educational Research 28 (2), 405-421.

Jansen, J. D. (2002). Political Symbolism as Policy Craft: Explaining Non-reform in South African Education After Apartheid. Journal of Educational Policy, 17(2), 199-215.

Jita, L.C., and Mokhele, M. L. (2013). The Role of Lead Teachers in Instructional Leadership: A Case Study of Environmental Learning in South Africa. Education as Change 17 (S1), S123-S135. Maitlis, S., and Christianson, M. 2014. Sense-making in Organisations: Taking Stock and Moving Forward. The Academy of Management Annals, 8(1), 57-123.

Mapetere, K. (2013). The New History Concept. Greener Journal of Educational Research, 3(3), 134-137.

McLaughlin, M. W. (1987). Learning from Experience: Lessons from Policy Implementation. Educational Evaluation and Policy Analysis, 9(2), 171-178.

McLaughlin, M. W., and Mitra, D. (2001). Theory-based Change and Change-based Theory: Going Deeper, Going Broader. Journal of Educational Change, 2(4), 301-323.

Minichielo, V., and Kottler, J. (2010). An Overview of the Qualitative Journey: Reviewing Basic Concepts. In Qualitative Journey: Students and Mentor Experiences with Research, edited by Minichielo, V. and J. Kottler. New Delhi: Sage.

Ministry of Education and Culture, Zimbabwe. 1990. 'O' Level Syllabuses for Candidates in Zimbabwe. History 2166. Harare: UCLES. 
MOPSE (Ministry of Primary and Secondary Education). 2015. Curriculum Framework for Primary and Secondary Education 2015-2022. Harare: MOPSE.

MOPSE (Ministry of Primary and Secondary Education). 2017. Secretary's Circular No. 2 of 2017: Implementation of the Curriculum Framework 2015-2022. Harare: MOPSE.

Moyo, N. (2014). Nationalist Historiography, Nation-state Making and Secondary School History: Curriculum Policy in Zimbabwe 1980-2010. Nordidactica - Journal of Humanities and Social Science Education, 2, 1-21.

Moyo, N., and Modiba, M. (2013). 'Who Does this History Curriculum Want You to Be?' Representation, School History and the Curriculum in Zimbabwe. Yesterday \& Today, 10, 1-24.

Patton, M. Q. (2002). Qualitative Research and Evaluation Methods. London: Sapes.

Phiri, D. (2015). New Education Curriculum is Actually a Mess. Zambian Watchdog, March 3.https://www.zambianwatchdog.com/new-school-curriculum-is-actually-a-mess/

Prendergast, M., and Treacy, P. (2017). Curriculum Reform in Irish Secondary Schools: A Focus on Algebra. Journal of Curriculum Studies, 50(1), 126-143. http://dx.doi.org/10.1080/00220272.2017.1313315

Reese, W. J. (2013). In Search of American Progressives and Teachers. History of Education, $42(3), 320-334$.

Sahlberg, P. (2006). Education Reform for Raising Economic Competitiveness. Journal of Educational Change, 7(3), 23-31.

Spillane J. P., Reiser, B. J., and Reimer, T. (2002). Policy Implementation and Cognition: Reframing and Refocusing Implementation Research. Review of Educational Research, 72(3), 387-431.

Spillane, J. P. (1999). State and Local Government Relations in the Era of Standards-based Reform: Standards, State Policy Instruments, and Local Instructional Policy Making. Educational Policy, 13(4), 546-572.

Tabulawa, R. (2009). Education Reform in Botswana: Reflections on Policy Contradictions and Paradoxes. Comparative Education, 45(1), 87-107.

Weick, K. E. (1995). Sense-making in Organisations. London: Sage.

Wheat, A., Attfield, S., and Fields, B. (2016). Developing a Model of Distributed Sensemaking: A Case Study of Military Analysis. Informatics, 3(1), 1-16. doi:10.3390/informatics3010001

ZIMSEC (Zimbabwe Schools Examinations Council). (2002). Ordinary Level Syllabus: History 2167. Harare: ZIMSEC.

Zindi, F. (2018). Zimbabwean Teachers' Concerns Regarding the Implementation of the New Curriculum. Zimbabwe Journal of Educational Research, 30(1), 25-35. 


\title{
Pasirengę, bet negalintys? Mokytojų mokymo programos reformos politika ir jos prasmès suvokimas ankstyvuoju igyvendinimo etapu
}

\author{
Godsend T. Chimbi ${ }^{1}$, Loyiso C. Jita ${ }^{2}$
}

Laisvosios valstijos universitetas, Edukologijos fakultetas, pašto děžutė 339, ZA-9300, Blumfonteinas, Pietų Afrikos Respublika,gchimbi1967@gmail.com

2 Laisvosios valstijos universitetas, Edukologijos fakultetas, pašto dèžutė 339, ZA-9300, Blumfonteinas, Pietų Afrikos Respublika, JitaLC@ufs.ac.za

\section{Santrauka}

Šiame straipsnyje dèmesys sutelkiamas ị tai, kas vyksta mokytojų protuose, kai jie susiduria su naujos reformos politika. Naudojantis teoriniu mokytojų prasmès suvokimo pagrindu ištirta, kad mokytojams pirmiausia reikia suprasti reformos politiką, ją tinkamai interpretuoti, kad jie galètų ịvertinti naujos politikos vertę ir susidomètų numatomu mokymo programos pokyčių igyvendinimu. Jei mokytojams nebus suteikta galimybė suvokti politikos signalų, jie nesirūpins reformomis ir nebenorès igyvendinti naujų pokyčių savo klasėse. Nors mokytojams iš pradžių nepatiko netikètas ir atsitiktinis reformos igyvendinimas, tyrimas nustate, kad mokytojai jau yra igyvendinę naujosios programos aspektus ir be papildomo mokymo bei personalo tobulinimo. Gali būti, kad mokytojai yra labiau pasirengę igyti naujų žinių ir ịgūdžių, tačiau yra neatsparūs mokymo programos pokyčiams. Šios išvados paneigia paplitusį mitą, kad mokytojai yra sabotuotojai, kurie kenkia mokymo programos reformoms, kvestionuojančioms jų turimas žinias ir îgūdžius. Keliama prielaida, kad mokytojų žinių ir igūdžių stoka netrukdo naujos reformos politikos igyvendinimui, jei tik mokytojai supranta pagerinimų, kuriuos tikisi igyvendinti, prasmę. Straipsnyje pateikiamos naujos ịžvalgos, kaip skatinti pokyčius ankstyvaisiais ir vèlesniais naujos mokymo programos igyvendinimo etapais Zimbabveje ar kitose šalyse. Mūsų nuomone, reikia atsisakyti tradicinès prielaidos, kad mokytojų ir mokyklų santykis su mokymo programų pokyčiais yra konservatyvus ir priešiškas. Tolimesniuose tyrimuose reikès išsiaiškinti, kaip mokytojų politikos signalų prasmès suvokimas pasikeitė erdvejje, laike bei skirtingų dalykų srityse.

Esminiai žodžiai: mokymo programos reforma, politika, prasmès suvokimas, reformos igyvendinimas, istorijos mokymo programa, istorijos mokytojas. 